\title{
MACRO AND BANK SPECIFIC DETERMINANTS OF NON-PERFORMING LOANS IN POLISH COMMERCIAL BANKS
}

The aim of this paper was to examine the determinants of non-performing loans (NPLs) in Polish commercial banks, and investigate the bank specific and macroeconomic determinants of NPLs for a panel of 18 banks from Poland, using annual data for the period 2005-2018. The authors applied four alternative estimation techniques: the fixed effects model, the random effects model, the difference Generalized Method of Moments and the system Generalized Method of Moments. The analyses show the bank-specific determinants, with the impact on the amount of NPLs including greturn on equity and growth of gross loans, while from the macroeconomic determinants the most important factors are: GDP growth, domestic credit to private sector, public debt and unemployment.

Keywords: non-performing loans (NPLs); macroeconomic determinants; bank-specific determinants; Poland; Generalized Method of Moments

JEL Classification: E32, E44, E51, G21

DOI: $10.15611 /$ aoe.2021.2.06

\section{INTRODUCTION}

Over the last two decades, the globalised technological change and the deregulation of goods and financial markets have intensified competition among banks. According to Jung (2013), competition has increased banks' credit risk, i.e. affected their loan portfolios in terms of their bad loan screening procedures and relaxing borrowing criteria. Moreover, the credit risk of the banks is very often linked to the ratio of NPLs which can be generally defined as loans in default or close to being in default. Brownbridge (1998) pointed out what was confirmed over the past decades that most of the banking failures or crises were caused by NPLs, e.g. the 1997 Asian financial crisis - Yang et al. (2003), and the 2008 global financial crisis - Diwa (2010). Furthermore, according to Khemraj and Pasha (2009),the increase of NPLs has been associated with bank failures and financial crises in both developing and

\footnotetext{
* Faculty of Economics, Ss. Cyril and Methodius University in Skopje, Republic of North Macedonia.

** Bank official in the Silk Road Bank, Ohrid, Republic of North Macedonia.
} 
developed countries. This was confirmed during the global financial crisis of 2007-2008, when the levels of NPLs significantly increased across countries. Whereas almost all countries in the world were faced with rapid growth of NPLs after the crisis, the growth varied significantly among different groups of countries, and within them. For example, in 2008 the number of NPLs as a share of total loans in high-income countries from the Organization for Economic Co-operation and Development (OECD) was 3\%, and increased to $8 \%$ in 2014, while in Central and South-East Europe it was 4\% in 2002, and reached almost $15 \%$ in 2014 .

The Polish economy is one of the most advanced among the Central and Eastern European (CEE) countries. According to Eurostat and the European Commission, its economy has been one of the fastest growing among the EU Member States (GDP grew by $4.6 \%$ in 2017). Furthermore, the financial system in Poland is dominated by the banking sector, which comprises $80 \%$ privately owned banks and several state-owned ones. Foreign capital is also a common occurrence in Poland's banking sector, accounting for $60 \%$ of total banking assets. At the end of 2017 the Polish financial landscape was made up of 35 commercial banks, 553 cooperative banks and 28 branches of credit institutions, while in 2017 the owners structure of the Polish banking sector changed, when the Polish banking sector's assets totalled $€ 427.17$ billion. A prudent credit policy and relatively good results of the Polish economy have allowed banks to maintain the NPL ratio at a relatively low level (6.8\%), lower than at the end of 2016(The European Banking Federation,2018).

In view of the above, the objective of this paper was to examine how the bank-specific and macroeconomic determinants affect the level of NPLs in Polish commercial banks. Many studies have explored the determinants of NPLs in many countries and regions, but only a relatively small number of authors included the Polish banking sector in their research. To the best of the authors' knowledge, only one relevant study (Głogowski, 2008) examined the determinants of NPLs in Poland, but it covered the period before the global financial crisis (1996-2006).The determinants of NPLs of Polish banks were also analysed in four-country panel studies conducted by Çifter (2015), Jakubík and Reininger (2013), Erdinc and Abazi (2014), but only as part of a group of countries in Central, Eastern, and South-East Europe (CESEE) and never as a single country.

Thus this paper offers a novel approach to the issue of NPLs in Poland by employing an unbalanced panel of 18 banks in Poland representing $80 \%$ of the total assets of Polish banks, using annual data from 2005 to 2018. The selected period covers mainly the crisis and post-crisis times, as well as the last three years of the pre-crisis boom (2005-2007). In order to avoid the risk of providing 
inconsistent and biased results, the study used four estimation models (the fixed effects model, the random effects model, the difference Generalized Method of Moments and the system Generalized Method of Moments).

The structure of the paper is as follows: Introduction, Section 2 reviews the literature on empirical findings relevant for both the macroeconomic and bank level determinants of NPLs. The sources of the data are presented in Section 3. In Section 4 the methodology is presented, while Section 5 explains the analysis and empirical results of the determinants of NPLs. Section 6 provides the findings and conclusion.

\section{LITERATURE REVIEW}

After the financial crisis of 2007-2008, the studies which investigated the determinants of banks' NPLs gained in importance (Khemraj and Pasha, 2009). Although the empirical results of studies differ, there are also some common elements, namely NPLs are usually measured by the ratio of NPLs to total loans, while as determinants they usually consist of bank-specific variables, and macroeconomic determinants. In the conclusion of this paper, the authors give a short summary of the empirical literature that emphasises NPL determinants in Poland.

To the best of the authors knowledge, only one relevant study (Glogowski,2008), analysed the determinants of NPLs of 108 Polish banks in the period between 1996 and 2006,applying panel fixed and random effects models. Glogowski used only macroeconomic determinants (rate of loans issued to households and corporations, real GDP growth, bank-level credit growth and share of real estate loans in loans to households borrower debt burden).

The author found evidence on the importance of the set of macroeconomic variables, consisting of real GDP growth, real interest rates and unemployment.

Out of the panel studies that analysed CESEE countries, this paper focused on four- country panel studies (Çifter, 2015; Jakubíkand Reininger, 2013; Erdincand Abazi, 2014).

Çifter (2015) examined the effects of the concentration of banks on NPLs in ten Central and East European (CEE) countries. The short-term effect of bank concentration is tested with the system Generalised Method of Moments and the instrumental variable approaches, and the long-term one was tested with the fully modified Ordinary Least Square(FMOLS) approach. The results show that bank concentration is an insignificant factor on NPLs, both in the short and in the long-term of the panel data set. On the other hand, individual FMOLS results revealed that the concentration of banks reduces the NPLs in 
Estonia, Latvia, and Slovakia, while decreasing those in Bulgaria, Croatia, Lithuania, Poland, and Slovenia in the long run.

Using the difference GMM system GMM models, Jakubik and Reininger (2013) analysed the determinants of NPLs in nine CESEE countries, using several macro determinants: real GDP, private sector, national stock exchange index, credit-to-GDP ratio, exchange rate. The empirical results showed that real GDP growth is the main driver that is negatively correlated with the dynamics of NPLs.

Erdincand Abazi (2014) analyzed determinants of NPLs in 20 emerging European countries, using several panel methods (fixed and random effects, difference and system GMM) and annual data from 2000 to 2011. The empirical results showed that real GDP growth, inflation rate and bank profitability have a significant impact on NPLs. The results also suggest that higher lending rates may lead to adverse selection problems, and hence reduce the loan quality.

\section{DATA SOURCE AND SAMPLE CHARACTERISTICS}

This study used an unbalanced panelof18 banks in Poland. The data from 2005-2018are based on the annual frequency. According to Rinaldi and Sanchis-Arellano (2006), unbalanced panel data include more observations and their results are less dependent on a particular period.

The data used in the empirical analysis came from two main sources. The data for the bank-specific determinants (equity to total assets ratio, ROE and growth of gross loans) were obtained from the Bankscope database of Bureau van Dijk. The financial information was derived from balance sheets, income statements, and notes from the annual reports. Bankscope had up to 20years' of data available, covering the total sample period. The data for the macroeconomic variables - GDP growth (annual percentage), unemployment, inflation, consumer prices (annual percentage), domestic credit to private sector (percentage of GDP) -public debt, and fiscal position (budget surplus deficit) as a percentage of GDP, were obtained from the World Development Indicators database. The selection of the variables included in the paper was influenced by the previously reviewed literature where selected variables were typically used, and the availability of data.

In this presentation of the independent variable, the authors considered both bank-specific and the macroeconomic characteristics. The factors used as control variables, which may explain the NPLs of banks were:

- Macroeconomic variables: real GDP growth - GDPG; inflation - INF; unemployment - UN; domestic credit to private sector (\% of GDP) - 
DCPS; public debt - PD; fiscal position (budget surplus or the budget deficit) as a percentage of GDP - FISCALP.

- Bank-specific variables: equity to total assets - ETA; return on equity ROE; growth of gross loans - GGL.

As discussed in the introduction, the economic model used in the empirical analysis covers bank-specific and macroeconomic variables and their potential impact on NPLs. In this paper, the dependent variable is the logit transformation of the ratio of impaired loans (NPLs) to total (gross) loans, as this transformation ensures that the dependent variable spans the interval $(-\infty,+\infty)$, as opposed to the interval between 0 and 1, and is distributed symmetrically (Salas and Saurina, 2002; Espinoza and Prasad, 2010).

\subsection{Macroeconomic variables}

Nkusu (2011), Skarica (2013), Klein (2013), Beck et al. (2013), use the real GDP growth as the main macroeconomic determinant of NPLs. With this in mind,the authors included the annual growth rate of real GDP in the analysis. The literature notes that when there is a slowdown in the economy, a rise in the NPLs can be observed (Skarica, 2013). Therefore, one anticipates a negative relationship between GDP growth and NPLs.

Inflation as the general consumer prices' increase is another macroeconomic factor that was investigated, particularly because of the unclear and ambiguous evidence that underpins this variable. Thus, higher inflation can make debt servicing easier by reducing the real value of outstanding loans. On the other hand, inflation can decrease the real income in the long run, and therefore leaving the debtors with a smaller amount of funds for repaying their debt. In the literature, many authors (Fofack, 2005; Rinaldi and Sanchis-Arellano, 2006; Skarica, 2013; Klein, 2015) found a positive correlation between the inflation rate and NPLs. However, a negative relation between these two determinants was observed by Vogazias and Nikolaidu (2011), therefore, one does not expect precise results with regard to it.

In order to show the level of indebtedness of the private sector in the economy, the authors included the level of domestic credit to the private sector (\% of GDP) in the model. According to Pesola (2005), and Nkusu (2011), high levels of debt make debtors much more vulnerable to adverse shocks which directly affect their income and, therefore, their ability to service their obligations. Hence with this variable one expects a positive correlation with the NPLs.

The last macroeconomic determinant used in this model was unemployment, which is the control variable for the health of the economic environment and 
is also closely related to the banks' performance. Regarding unemployment, bank performance suffers when unemployment increases because there will be fewer individuals seeking to cooperate with banks, and fewer bank accounts and services, which leads to increased NPLs. In other words, according to Messai and Jouini (2014), a rise in the unemployment rate actually limits the current and future purchasing power of households and enterprises, and also adversely affects their cash flows and therefore, the increasing debt burden accompanies the increasing unemployment rate. Empirical studies that investigated the relation between unemployment and NPLs found a positive correlation (Głogowski,2008;Makriet al., 2014; Messai and Jouini, 2014). Thus, based on the above arguments there is a positive relation between unemployment and NPLs.

\subsection{Fiscal variables}

In some European countries, the 2008/2009 crisis first affected fiscal indices and then extended to the banks. Taking this point into consideration, the authors included two public finance variables (DEBT and FISCALP) in the research. First, the study used public debt which is a form of financial obligation incurred by the government or borrowings and repayments. With this determinant, the authors expected a positive relationships with NPLs, since an additional increase of public debt can influence the credit ratings of the government and consequently the liquidity of the banks. In other words, the banks tend to invest their liquidity reserves in government securities and with the deterioration of the government credit rating, the rating of government securities is also affected. In this way, the banks continue their operation under the pressure of liquidity. According to Reinhart and Rogoff (2010), the need to deal with the liquidity pressure limits the banks' placement of loans and as a result, the debtors cannot renew their loans - which can cause an increasing trend in the level of NPLs. In other words, it has been posited that banking and sovereign crises are closely connected, and banking crises in factcan either precede or be the result of a sovereign crisis as in the case of Greece (Louzis et al., 2012).

The second fiscal determinant employed in this model was the government's fiscal position (budget surplus or deficit) as a percentage of GDP. According to Hyde(2002), a surplus can indicate an increase in taxes or a decrease in government expenditure or both at the same time, while a deficit implies a decrease in tax revenues and a rise in government expenditure or both at the same time. According to Makri et al.(2014),since a variable FISCALP has by 
its nature an adverse relationship with PD, it is expected to be negatively correlated with NPLs. In other words, this negative correlation is due to the fact that it can indicate a better fiscal position of the country, less expensive financing, and reduced risk, and expectations of a sustainable fiscal position are improved. Bearing this in mind, the authors expected a negative correlation with NPL in the case of this determinant.

\subsection{Bank-specific variables}

The first determinant used in the model was the profitability ratio (ROE) as a measure of banks' past performance, because banks' profitability is linked to their risk-taking behaviour. Swamy (2012 ) pointed out that if the banks are more profitable this will lead to lower levels of NPLs. The vast majority of the literature observed the negative impact of the profitability ratios on NPLs (Godlewski, 2004; Louzis et al., 2010; Makri et al., 2014; Messai and Jouini, 2014). According to Makri et al. (2014), this relation is due to the poor performance of the banks decreased profitability, which further motivates managers to lend to riskier borrowers in order to raise profitability, which eventually leads to the growth of NPLs. Therefore one expects a negative sign withth is explanatory variable.

The share of equity in total assets was the next determinant included in the model. In most studies (Berger and DeYoung, 1997; Salas and Saurina, 2002; Klein, 2013), there is a negative relation between equity in total assets and NPLs, yet there are studies where this connection can be positive (Rajan and Dahl, 2003;Boudriga et al., 2009; Espinoza and Prasad, 2010). According to Quagliarello (2007), the positive relation is due to the fact that the higher the risk appetite of a bank, the greater the share of capital to existing shareholders invested in the bank, in order to convince other shareholders to invest in and support the bank. Hence in the case of this determinant, the authors expected an ambiguous correlation with NPLs.

According to Petkovski et al. (2018), the credit policy of the bank plays a significant role in determining the subsequent levels of NPLs. In order to maximise the short-run benefits, managers seek to rapidly expand credit activities and therefore, may take inadequate credit exposures (Castro, 2012; Beck et al., 2013; Klein,2013). In the literature, the results based on this determinant are mixed. For example, Dash and Kabra (2010) indicated the presence of a positive correlation between credit growth and NPLs, while Swamy (2012) found a negative correlation. Therefore, the authors expected an ambiguous correlation with NPLs. 
Table 1

Descriptive statistics

\begin{tabular}{l|c|c|c|c|c|c|c|c|c|c}
\hline & NPL & ROE & ETA & GGL & GDPG & DCPS & INF & UN & PD & FISCALP \\
\hline Mean & 7.62 & 10.0 & 11.0 & 15.7 & 3.96 & 47.1 & 1.96 & 9.10 & 50.3 & -3.62 \\
\hline Median & 6.67 & 10.4 & 10.4 & 10.1 & 3.72 & 50.5 & 2.12 & 9.29 & 50.4 & -3.65 \\
\hline Maximum & 40.0 & 38.1 & 42.2 & 157.7 & 7.03 & 54.5 & 4.23 & 17.7 & 55.7 & -0.4 \\
\hline Minimum & 0.19 & -25.2 & 0.71 & -87.2 & 1.39 & 27.1 & -0.87 & 3.8 & 44.2 & -7.3 \\
\hline Std. Dev. & 5.29 & 7.61 & 4.91 & 26.41 & 1.52 & 8.4 & 1.62 & 3.41 & 3.42 & 1.88 \\
\hline Observations & 182 & 211 & 225 & 202 & 252 & 252 & 252 & 252 & 252 & 252 \\
\hline
\end{tabular}

Source: authors' calculations.

Table 1 presents the descriptive statistics for the determinants involved in the regression model. Based on the data, one can say that there are significant differences among the banks in Poland in terms of all the variables selected. Namely, in the case of ROE, there are banks where this determinant has a negative value of -25.2 , but it can also go up to as much as 38.1 , which is similar with the other variables. This is also the case of the macroeconomic variables, with large oscillations in the analysed period, especially unemployment (UN), which has the largest variations between the minimum and the maximum values.

\section{METHODOLOGY}

The main objective of this study was to examine the impact of bankspecific and macroeconomic factors on the volume of NPLs using panel data for a sample of 18 banks from 2005 to 2018. According to Hsiao (2014), panel analyses have several benefits: (1) increasing degrees of freedom and reducing problems of data multicollinearity, (2) constructing more realistic behavioural models and discriminating between competing economic hypotheses, (3) eliminating or reducing estimation bias, (4) obtaining more precise estimates of micro relations and generating more accurate micro predictions, (5) providing information on appropriate level of aggregation, and (6) simplifying cross sections or time series data inferential procedures.

Therefore, a precise econometric model was developed incorporating all the widely recognized variables mentioned above. The model was also summarized in accordance with the existing models in the extensive literature, and the variables involved are also supported by substantial empirical evidence.

In order to explore the relations between selected determinants and NPLs, this paper employed four different models: the fixed effects model, the random 
effects model, the difference GMM and the system GMM, as well as the necessary relevant tests which are explained more specifically further in the paper.

The starting point in each panel model was the assessment of fixed and random effects. They are well documented in the literature, for example, in Wooldridge (2007). In short, the analysis of fixed effects assumes that the units of interest (in this case, the banks) are fixed, and that the differences between them are not of interest. However, the random-effects model, provides a lock to the population from which the sample was extracted. For the authors' analysis of the banks, the fixed effects model was appropriate. Thus, in short panels the estimates obtained can differ considerably and the fixed effects should therefore be employed when the authors strongly believe that the units in the model are not random drawings from a larger sample, in which case the random-effects model is preferred. In addition, the authors also conducted the Hausman test (1978)to distinguish between the models of fixed and random effects.

The models of fixed and random effects imply that all the independent variables are exogenous. However, for some of them, it can be argued that there is a reciprocal causation, as part of them originate from the balance sheets of the banks themselves. Such feedback may cause inconsistency in the assessment of the model of fixed or incidental effects. In order to overcome this, the model can be evaluated by means of the so-called instrumental variables technique, in which potentially endogenous variables are instrumented with variables that are highly correlated with the particular regressor, but are not correlated with the error component(Wooldridge, 2007). In particular, the panel data prepared for this study was a linear functional relation, a dynamic left-handed variable, and not strictly exogenous as some of the variables and fixed effects that were observed with the first estimation technique. Accordingly, the structured model for the determinants of NPLs was a perfect match in the GMM estimation and therefore, it was decided to proceed with this technique to obtain more relevant and unbiased results. Additionally, following the previous papers with dynamic panel data, e.g. Makri et al. (2014), Klein (2013), Beck and Levine (2004), Cheng and Kwan (2000) similar to this one, the authors also focused on the objectives and handling an equivalent panel data set, utilized the difference GMM and the system GMM.

With the difference GMM one avoids the "dynamic panel bias" in the fixed effects model by transforming the data to first differences to remove the fixed effects and uses the lagged levels of the right-handed independent variables as instruments. Still, in panel datasets with limited time dimension or lower T 
(such as in this case), this estimation can be less precise, according to Blundell and Bond (1998). As a result, the system GMM is applied in order to avoid this concern. This approach actually involves two equations: one in levels in which the instruments are presented by the lagged first differences, and the other in the first differences with lagged levels as instruments(Arellano and Bover, 1995). Under this approach, the lagged bank level variables were modelled as pre-determined (thus instrumented GMM-style in the same way as the lagged dependent variable), while the country-level and the global variables were treated as strictly exogenous (instrumented by itself as a "IV style" instrument; Roodman, 2009).

However, the equation that the authors aimed to estimate in this paper to observe the impact of the bank-specific and macroeconomic variables on NPLs is the following:

$$
\begin{gathered}
N P L_{i t}=\alpha_{o}+N P L_{i t-1}+\sum_{j=1}^{J} \beta_{j} E T A_{i t}^{j}+\sum_{k=1}^{K} \delta_{k} R O E_{i t}^{k}+ \\
+\sum_{i=1}^{L} \gamma_{i} G G L_{i t}^{l}+\sum_{m=1}^{M} \varphi_{m} G D P G_{i t}^{m}+\sum_{n=1}^{N} \lambda_{n} D C P S_{i t}^{n}+ \\
+\sum_{p=1}^{P} \rho_{p} I N F_{i t}^{p}+\sum_{r=1}^{R} \tau_{r} U N_{i t}^{r}+\sum_{s=1}^{S} \omega_{s} P D_{i t}^{s}+\sum_{z=a}^{Z} \zeta_{z} F I S C A L P_{i t}^{z}+v_{i t}+\varepsilon_{i t}
\end{gathered}
$$

where: $N P L_{i t}$ denotes non-performing loans to total gross loans, $\alpha_{0}$ is the intercept, ETA, ROE and GGL denote the bank-specific factors, GDPG, DCPS, INF, UN, PD and FISCALP represent the macroeconomic variables, $v$ is the unobservable bank-specific variable and $\varepsilon$ denotes the remaining disturbance term. The subscripts $i$ denote individual banks, $i=1,2, \ldots, 18$, and $t$ is the time period, $t=2005, \ldots 2018$.

This equation also incorporates the lagged dependent variable that was excluded earlier from the fixed effects estimation since the former can result in "dynamic panel bias" and the latter will be absorbed by the model's intercept. Nevertheless, the reasons behind the choice of the Arellano-Bond GMM estimator were elaborated above.

Based on this, further analysis evaluates through three panel methods: the method of fixed effects, the GMM difference method and the system GMM method. The choice between the fixed and random effects was made based on the Hausman test (1978). The validity of the instruments selected for parametric evaluation can be tested using the Sargan test. The second group of tests refers to tests of serial correlations in different residuals (first-order $\mathbf{A R ( 1 )}$ and second-order $\mathbf{A R ( 2 )}$ serial correlation). The first-order autocorrelation in the 
differed residuals does not imply that the estimates are inconsistent (Arellano and Bond, 1991: 282). However, the second-order autocorrelation would imply that the estimates are inconsistent.

\section{RESULTS AND DISCUSSION}

This section begins with an analysis of the results of multicollinearity. According to Kennedy (2008), multicollinearity is a problem when the correlation is above 0.80 , which was notthe case here. The matrix shows that in general, the correlation between the selected variables was not strong, suggesting that multicollinearity problems were either not severe or nonexistent.

Table 2

Correlation matrix

\begin{tabular}{l|c|c|c|c|c|c|c|c|c|c}
\hline & NPL & ROE & GGL & ETA & GDPG & DCPS & INF & UN & PD & FISCALP \\
\hline NPL & 1 & -0.20 & -0.26 & 0.34 & -0.09 & 0.003 & -0.09 & 0.08 & 0.10 & -0.10 \\
\hline ROE & -0.20 & 1 & 0.05 & 0.01 & 0.21 & -0.42 & 0.18 & 0.35 & -0.30 & 0.06 \\
\hline GGL & -0.26 & 0.05 & 1 & -0.18 & 0.20 & -0.14 & 0.09 & 0.06 & -0.16 & -0.04 \\
\hline ETA & 0.34 & 0.01 & -0.18 & 1 & -0.06 & 0.03 & -0.01 & -0.005 & 0.03 & 0.02 \\
\hline GDPG & -0.09 & 0.21 & 0.20 & -0.06 & 1 & -0.38 & 0.11 & -0.07 & -0.67 & 0.38 \\
\hline DCPS & 0.003 & -0.42 & -0.14 & 0.03 & -0.38 & 1 & -0.26 & -0.69 & 0.65 & 0.13 \\
\hline INF & -0.09 & 0.18 & 0.09 & -0.01 & 0.11 & -0.26 & 1 & 0.14 & -0.18 & -0.42 \\
\hline UN & 0.08 & 0.35 & 0.06 & -0.005 & -0.07 & -0.69 & 0.14 & 1 & -0.16 & -0.40 \\
\hline PD & 0.10 & -0.30 & -0.16 & 0.03 & -0.67 & 0.65 & -0.18 & -0.16 & 1 & -0.24 \\
\hline FISCALP & -0.10 & 0.06 & -0.04 & 0.02 & 0.38 & 0.13 & -0.42 & -0.40 & -0.24 & 1 \\
\hline
\end{tabular}

Source: authors' calculations.

The results of the unit root test are presented in Table 3. The unit root analysis, according to ADF Fisher-type tests cannot be rejected in three variables (UN, INF and DEFI), while the results of the PP Fisher-type tests indicate that the null hypothesis of non-stationarity can be rejected for all thevariabless. The results of the Breitung test indicate that the hypothesis of non-stationarity cannot be rejected for three of thevariables (NPL, DCPS and ETA). However, bearing in mind that the other two unit tests (ADF and PP Fisher-type) show that these variables are stationary at their levels, the authors included PD, DCPS and ETA in the models, and treated them as non-stationary variables at their levels. 
Table 3

Panel unit root tests

\begin{tabular}{l|c|c|c|c|c|c}
\hline \multirow{2}{*}{$\begin{array}{c}\text { Test } \\
\text { variables }\end{array}$} & \multicolumn{2}{|c|}{ ADF-Fisher chi square } & \multicolumn{2}{c|}{ PP-Fisher chi square } & \multicolumn{2}{c}{ Breitung } \\
\cline { 2 - 7 } & Level & $\begin{array}{c}\text { First } \\
\text { difference }\end{array}$ & Level & $\begin{array}{c}\text { First } \\
\text { difference }\end{array}$ & Level & $\begin{array}{c}\text { First } \\
\text { difference }\end{array}$ \\
\hline NPLs & $45.19 * * *$ & & $61.96^{* * *}$ & & $-1.534 *$ & \\
\hline PD & $0.793 * *$ & & $0.784 *$ & & 0.782 & $-3.727 * * *$ \\
\hline UN & 30.61 & $91.98^{* * *}$ & $66.07 * * *$ & & $-6.715^{* * *}$ & \\
\hline GDPG & $88.57 * * *$ & & $51.69 * *$ & & $-7.578^{* * *}$ & \\
\hline INF & 32.94 & $93.80 * * *$ & $14.5055^{*}$ & & $-4.756^{* * *}$ & \\
\hline DCPS & $162.3 * * *$ & & $443.6^{* * *}$ & & 3.624 & $-13.02 * *$ \\
\hline ROE & $59.66 * * *$ & & $98.56^{* * *}$ & & $-2.895 * * *$ & \\
\hline ETA & $46.70^{*}$ & & $82.21 * * *$ & & 0.558 & $-0.462 *$ \\
\hline GGL & $64.10^{* * *}$ & & $82.76^{* * *}$ & & $-2.537 * *$ & \\
\hline DEFI & 0.595 & $158.90^{* * * *}$ & $0.985^{*}$ & & $-4.190^{* * *}$ & \\
\hline
\end{tabular}

$* * *, * *, *$ denote statistical significance at the $1,5,10$ percent level, respectively.

Source: authors' calculations.

Table 4 presents the empirical results of the fixed effects model, the difference GMM and the system GMM.

The results presented in Table 4 broadly confirm that both bank-level and macroeconomic factors play a role in affecting the banks' asset quality. The models seem to fit the panel data reasonably well, having fairly stable coefficients. First, the Hausman test (with a $p$-value of 0.009) shows that one can reject the null hypothesis that the random effect model is preferred, and proceed with the estimation employing the fixed effects model. Thus, the Hausman test indicates that it is the fixed effects model that should be used during the estimation. Furthermore, the test shows that the chosen instruments are valid in the difference and the system GMM (with a $p$-value of 0.548 and 0.497, respectively). Additionally, the results under both models (the difference GMM and system GMM) show that the residuals demonstrate no serial correlation of order two, although a first order autocorrelation is present in both models, yet this does not imply that the estimates are inconsistent. According to Arellano and Bond (1991), inconsistency would be implied if a second-order autocorrelation was present, but this was rejected in this case by the test for $\mathrm{AR}(2)$ errors. 
Table 4

Estimation Results

\begin{tabular}{|c|c|c|c|c|}
\hline Variables & $\begin{array}{l}\text { Fixed Effects (FE) } \\
\text { regressions }\end{array}$ & $\begin{array}{l}\text { Random Effects (RE) } \\
\text { regressions }\end{array}$ & $\begin{array}{l}\text { Difference } \\
\text { GMM }\end{array}$ & $\begin{array}{l}\text { System } \\
\text { GMM }\end{array}$ \\
\hline NPL(-1) & & & $\begin{array}{c}1.263^{* * *} \\
(0.44)\end{array}$ & $\begin{array}{c}0.819^{* * *} \\
(0.23)\end{array}$ \\
\hline Const & $\begin{array}{l}15.06^{* *} \\
(7.35)\end{array}$ & $\begin{array}{c}10.84 * * * \\
(9.27)\end{array}$ & $\begin{array}{c}12.34 * * * \\
(7.32)\end{array}$ & $\begin{array}{c}10.06^{* * *} \\
(5.43)\end{array}$ \\
\hline ETA & $\begin{array}{l}-0.086 \\
(0.05) \\
\end{array}$ & $\begin{array}{l}0.339 \\
(0.07) \\
\end{array}$ & $\begin{array}{l}-0.312 \\
(0.27)\end{array}$ & $\begin{array}{l}-0.216 \\
(0.26)\end{array}$ \\
\hline ROE & $\begin{array}{l}-0.022 * \\
(0.01)\end{array}$ & $\begin{array}{l}-0.051 \\
(0.05)\end{array}$ & $\begin{array}{l}0.248 \\
(0.15)\end{array}$ & $\begin{array}{l}-0.074 \\
(0.11)\end{array}$ \\
\hline GGL & $\begin{array}{c}-0.034 * * * \\
(0.01) \\
\end{array}$ & $\begin{array}{l}-0.016 \\
(0.01) \\
\end{array}$ & $\begin{array}{c}0.002 * * \\
(0.02) \\
\end{array}$ & $\begin{array}{c}-0.016^{*} \\
(0.01) \\
\end{array}$ \\
\hline GDPG & $\begin{array}{c}-0.675^{* * *} \\
(0.27)\end{array}$ & $\begin{array}{c}-0.620^{* *} \\
(0.35)\end{array}$ & $\begin{array}{c}-1.522 * * * \\
(0.41)\end{array}$ & $\begin{array}{c}-0.943 * * * \\
(0.23)\end{array}$ \\
\hline DCPS & $\begin{array}{c}-0.387 * * * \\
(0.12)\end{array}$ & $\begin{array}{c}-0.308^{* *} \\
(0.15)\end{array}$ & $\begin{array}{l}-0.342 \\
(0.13)\end{array}$ & $\begin{array}{c}-0.313^{* * *} \\
(0.07)\end{array}$ \\
\hline INF & $\begin{array}{l}-0.038 \\
(0.19) \\
\end{array}$ & $\begin{array}{l}-0.216 \\
(0.24)\end{array}$ & $\begin{array}{l}-0.259 \\
(0.22) \\
\end{array}$ & $\begin{array}{l}0.240 \\
(0.18) \\
\end{array}$ \\
\hline UN & $\begin{array}{l}0.413 \\
(0.25) \\
\end{array}$ & $\begin{array}{l}0.371 \\
(0.32) \\
\end{array}$ & $\begin{array}{c}1.448^{* *} \\
(0.54) \\
\end{array}$ & $\begin{array}{c}0.645^{* * *} \\
(0.21) \\
\end{array}$ \\
\hline PD & $\begin{array}{c}0.360^{* *} \\
(0.16) \\
\end{array}$ & $\begin{array}{l}0.250 \\
(0.20) \\
\end{array}$ & $\begin{array}{c}0.448 * * * \\
(0.15)\end{array}$ & $\begin{array}{c}0.363 * * * \\
(0.12) \\
\end{array}$ \\
\hline DEFI & $\begin{array}{l}-0.212 \\
(0.19)\end{array}$ & $\begin{array}{l}-0.473 \\
(0.23)\end{array}$ & $\begin{array}{l}0.052 \\
(0.20)\end{array}$ & $\begin{array}{l}-0.021 \\
(0.11)\end{array}$ \\
\hline Number of Banks & 18 & 18 & 18 & 18 \\
\hline Hausman test (p-value) & \multicolumn{2}{|c|}{0.009} & & \\
\hline Number of instruments & & & 12 & 13 \\
\hline Hansen test (p-value) & & & 0.548 & 0.497 \\
\hline Test for AR(1) errors & & & 0.095 & 0.074 \\
\hline Test for $\mathrm{AR}(2)$ errors & & & 0.726 & 0.445 \\
\hline
\end{tabular}

1. Arellano-Bond test shows that the average autocovariance in residuals of order 1 is 0 (HB0B: No autocorrelation).

2. Arellano-Bond test indicates that the average autocovariance in residuals of order 2 is 0 (HB0B: No autocorrelation).

Standard errors are in parenthesis

$*, * *$ and *** show that the null hypothesis can be rejected at $10 \%, 5 \%$ and $1 \%$ significance levels respectively

Source: authors' calculation. 
The results for the lagged dependent variable have a positive and statistical significance in both of the models that estimated its coefficient, which is confirmed by the dynamic character of the model's specification. The values of lagged NPLs between 0.44 and 0.23 suggest that a shock to NPLs would be likely to have a prolonged effect on the Polish banking system. These results are similar to those obtained by previous studies(cf. Beck et al., 2005), where the value of lagged NPLs was between 0.19 and 0.29 , and likewise Otasevic (2014) reported the values of lagged NPLs between 0.12 and 0.27 .

Starting with bank-specific determinants, only individual credit growth has a statistically significant and negative relation with NPLs in three models (fixed effects, difference GMM and system GMM). Despite the theoretical justification of the positive relationship as mentioned before, there are also studies such as Swamy (2012), Boudriga et al. (2009), which established a negative link between these two variables. These results probably reflect the conservative lending stance adopted by commercial banks after 2002-2014 due to their bad lending experience with the real sector and the general decline in the real economy. In that period the amount of NPLs in Poland reached a record high of $22.6 \%$ in June 2003. This is in line with Quagliarello (2007),who argued that a positive result of GGL may be the result of certain specifics, regulation and history in the separate banking systems that they have, and that the banks are more conservative and more careful in the dissemination of the credit offer.

The ROE related results indicate that profitability has a significant and negative impact on NPLs, but only in the first model with a fixed effect with a value of -0.22 . The result is in line with the study by Klein(2013), where ROE was also statistically significant only under the fixed effects model, while not being significant under the difference GMM and system GMM.

The study found that GDP growth has a significant and negative impact on NPLs, which means that an increase in domestic product causes a decrease of NPLs in both models. The figures provide evidence that economic growth reduces the credit risk, i.e. NPLs, which actually provides evidence of accepting the hypothesis of pro-cyclicality of the credit risk. The results obtained are consistent with the results of Salas and Saurina (2002), Rajan and Dhal (2003), Quagliarello (2007), Louzis (2010), Nkusu (2011), Castro (2012), Klein (2013) and Beck et al. (2013). The fact that economic growth is statistically significant(at the level of significance of $1 \%$ ) in all the models is confirmed by the robustness of the results obtained.

The results of DCPS indicate a statistically significant explanation power with anegative sign of the NPLs. As before, the credit growth from bankspecific determinants also had a negative sign, which was not surprising. 
As was expected, unemployment has a positive and statistical significance at $1 \%$ and an impact on NPLs in the difference GMM and system GMM models. The increase in unemployment leads to an increase of NPLs, because when borrowers lose their sources of income they cannot repay their loans, which contributes to higher NPLs. With regard to enterprises, the rise of unemployment could lead to a decline in production due to the fall in effective demand.

The last macroeconomic variable that is statistically significant is public debt. The results indicate that this variable has a positive effect on NPLs in the three models. This relation highlights the fact that if Poland has fiscal problems this may lead to a substantial rise in NPLs. The positively significant coefficient of public debt with NPLs is also evident in the findings of Makri et al. (2014), Louzis et al. (2010) and Ghosh (2015).

One may conclude that the estimations for the overall period suggest that the selection of the independent variables is plausible and most of the regressors yield statistically significant coefficients, which also have the expected signs. Additionally, the difference GMM and system GMM models produce similar results, while the fixed effects model demonstrates quite different results in the case of some variables.

It is quite interesting that ROE is significant only under the fixed effects model, but the macroeconomic variables show statistical significance in all models. Such variables are DCPS, GDPG and PD. The only variable that is not significant in all models is UN.

In order to test the robustness of the results, the authors excluded the five smallest banks. The criteria used were the total asset of the banks in 2018 . Apart from the actual variables in the empirical model, the study also included two dummy variables that marked the global economic crisis. Thereby, DUM2008 had the value of 1 for the period in 2008 and 0 for all other periods, and DUM 2009 had the value of 1 for the 2009 and 0 for all other periods. Due to the consequential deterioration of economic activity, borrowers had more difficulties paying off their debts, therefore increasing the rate of NPLR; hence the authors expected a positive sign for the coefficient on these dummies. The robustness was tested using the difference GMM and system GMM.

These results confirm the reliability of the model. In fact, although the authors excluded the five smallest banks from the set of banks, the results were similar. Furthermore, the results show that the two dummy variables added to the model to mark the global economic crisis 2008/2009 had a significant impact of NPLs only in 2009 and when the system model was used. The results from the dummy variables were as expected, because, thanks to strict supervision, the Polish banking system is showing resilience and avoided serious problems in 2008/2009 Strojwas (2010). 
Table 5

Robustness analyses

\begin{tabular}{|c|c|c|}
\hline Variables & Difference GMM & System GMM \\
\hline NPL(-1) & $\begin{array}{c}0.707 * * * \\
(0.15)\end{array}$ & $\begin{array}{c}0.840 * * * \\
(1.02)\end{array}$ \\
\hline Const & $\begin{array}{c}7.52 * * * \\
(7.32)\end{array}$ & $\begin{array}{c}12.38 * * * \\
(5.43)\end{array}$ \\
\hline ETA & $\begin{array}{l}-0.321 \\
(0.34)\end{array}$ & $\begin{array}{l}-1.878 \\
(0.75)\end{array}$ \\
\hline ROE & $\begin{array}{c}-0.832 * \\
(0.46) \\
\end{array}$ & $\begin{array}{l}-0.055 \\
(0.33) \\
\end{array}$ \\
\hline GGL & $\begin{array}{l}0.020^{*} \\
(0.12)\end{array}$ & $\begin{array}{c}-0.103 * \\
(0.08)\end{array}$ \\
\hline GDPG & $\begin{array}{c}-1.014^{* * *} \\
(1.34)\end{array}$ & $\begin{array}{c}-0.610^{* * *} \\
(0.23)\end{array}$ \\
\hline DCPS & $\begin{array}{c}-0.457 * * * \\
(0.62)\end{array}$ & $\begin{array}{c}-0.519 * * * \\
(0.78)\end{array}$ \\
\hline INF & $\begin{array}{l}0.005 \\
(0.15) \\
\end{array}$ & $\begin{array}{l}0.352 \\
(0.43) \\
\end{array}$ \\
\hline UN & $\begin{array}{c}0.733^{* *} \\
(0.19) \\
\end{array}$ & $\begin{array}{c}0.306^{* * *} \\
(1.01)\end{array}$ \\
\hline $\mathrm{PD}$ & $\begin{array}{c}0.385 * * * \\
(0.15)\end{array}$ & $\begin{array}{c}0.344 * * * \\
(0.28)\end{array}$ \\
\hline DEFI & $\begin{array}{l}-0.112 \\
(0.11)\end{array}$ & $\begin{array}{l}-0.041 \\
(0.45)\end{array}$ \\
\hline DUM2008 & $\begin{array}{c}0.42 \\
(0.16) \\
\end{array}$ & $\begin{array}{c}0.19 \\
(0.57) \\
\end{array}$ \\
\hline DUM2009 & $\begin{array}{l}0.11^{*} \\
(0.12)\end{array}$ & $\begin{array}{c}0.22 \\
(0.32)\end{array}$ \\
\hline Numberof banks & 13 & 13 \\
\hline Numberofinstruments & 12 & 13 \\
\hline Hansentest(p-value) & 0.726 & 0.685 \\
\hline TestforAR(1)errors & 0.057 & 0.055 \\
\hline TestforAR(2)errors & 0.776 & 0.929 \\
\hline
\end{tabular}

Notes: 1 . The Arellano-Bond test shows that the average auto-covariance in residuals of order 1 is 0 (H0no autocorrelation). 2. The Arellano-Bond test indicates that the average autocovariance in residuals of order 2 is 0 (H0no autocorrelation).

Standard errors are inparentheses

$*, * *$ and *** show that the null hypothesis can be rejected at $10 \%, 5 \%$ and $1 \%$ significance levels, respectively.

Source: authors' calculation. 
The main conclusion of this paper is that the NPLs in Poland are generally shaped by the macroeconomic factors in the period analysed. Second, the factors that demonstrate a statistically significant and positive correlation with the NPLs ratio are the following: the lagged non-performing loans ratio, the GGL, and ROE from the group of bank-specific factors, as well as the GDPG, DCPS, UN and PD from the group of macroeconomic factors. In addition, the signs of these variables are in line with the initial expectations.

To sum up, one may conclude that in the period between 2005 to 2018 the NPLs were mostly influenced by macroeconomic factors. This paper found that bank-specific factors also have an impact, although a relatively smaller one, on the level of NPLs. Bearing this in mind, the banking sector in Poland should continue to further improve the quality of their management, despite the theoretical justification of the positive relation between credit growth and NPLs. In this case, the relationship has a negative value which confirms that banks in Poland are well-managed in terms of approving and collecting loans again.

\section{CONCLUSION}

The first part of this paper examined the bank-specific and macroeconomic variables of NPLs for a panel of 18 banks from Poland, using annual data for the period 2005-2018. The study employed four alternative estimation techniques: the fixed effects model, the random effects model, the difference Generalized Method of Moments and the system Generalized Method of Moments. During the research, the authors could not find another empirical paper that is focused entirely on the issue of macroeconomic and bank specific determinants of NPLs in Poland, with one exception, which only covered the period before the global financial crisis (1996-2006).

Based on the empirical results one can see that relatively different results are shown through the four alternative estimation techniques. The general conclusion is that in the period under consideration, the NPLs in Poland were mostly shaped by macroeconomic factors. Specifically, it was found that, from among the macroeconomic variables, GDP growth and domestic credit to the private sector had a strong negative effect on the level of NPLs, while public debt and unemployment had a positive one. This paper also found that out of the bank-specific factors, individual credit growth in the case of three models (fixed effects, difference and system GMM) demonstrates statistically the most significant and negative relations with NPLs. 
The authors have several suggestions for further research. First, it could be interesting for future studies to extend the sample and comparatively analyse certain countries similar to Poland (e.g. the Czech Republic) in order to elucidate the factors that affect NPLs. Second, as a measure of credit risk, it would be beneficial to also apply changes in the status of NPLs, or bad debt reserves, along with the ratio of NPLs over total loans. Third, future studies could provide a breakdown of all NPLs to NPLs to enterprises and to households and then apply such a breakdown of NPLs to enterprises by type of activity and to households by type of loan. Such findings could help policymakers to identify the loan categories that are mostly exposed to NPLs, and consequently to concentrate on those categories in order to mitigate the credit risk and streng then the financial stability of the country.

\section{REFERENCES}

Arellano, M., Bover, O., Another look at the instrumental variable estimation of errorcomponents models, Journal of Econometrics, Vol. 68, pp. 29-51, 1995.

Arellano, M., Bond, S., Some tests of specification for panel data. Monte Carlo evidence and an application to employment equations, Review of Economic Studies, 58, pp. 277-297, 1991.

Blundell, R., Bond, S., Initial conditions and moment restrictions in dynamic panel data models. Journal of Econometrics, 87, pp. 115-143, 1998.

Beck, T., Levine, R., Stock markets, banks, and growth: Panel evidence, Journal of Banking \& Finance, 28(3), pp. 423-442, 2004.

Beck, R., Jakubik, P., Piloiu, A., Non-performing loans. What matters in addition to the economic cycle? Working Paper Series, No. 1515, European Central Bank, pp. 1-32, 2013.

Beck, T., Demirgüç-Kunt, A., Maksimovic,V., Financial and legal constraints to firm growth: does firm size matter?, Journal of Finance, Vol. LX, No. 160, pp. 137-177, 2005.

Berger, A., DeYoung, R., Problem loans and cost efficiency in commercial banks, Journal of Banking and Finance, 21, pp. 849-870, 1997.

Boudriga, A., Boulila, N., Jellouli, S., Does bank supervision impact nonperforming loans: cross-country determinants using aggregate data?, MPRA Paper, No. 18068, pp. 1-28, 2009.

Brownbridge, M., The causes of financial distress in local banks in Africa and implications for prudential policy, Discussion papers (UNCTAD), 1998.

Castro, V., Macroeconomic determinants of the credit risk in the banking system: The case of the GIPSI. "NIPE WP," 11/ 2012, pp. 1-29, 2012.

Çifter, A., Bank concentration and non-performing loans in Central and Eastern European countries, Journal of Business Economics and Management, Vol. 16, Issue 1, pp. 17-137, 2015.

Dash, M., Kabra, G,. The determinants of non-performing assets in Indian commercial banks: an econometric study, Middle Eastern Finance and Economics, No. 7, pp. 94-106, 2010. 
Diwa, G., The impact of the global financial crisis on the Philippine financial system: an assessment, BIS Papers No 54, pp. 317-343, 2010.

Erdinc, I., Abazi, E., The determinants of NPLs in emerging Europe, 2000-2011, Journal of Economics and Political Economy, Vol. 1, Issue 2, pp. 112-125, 2014.

Espinoza, R., Prasad, A., Nonperforming loans in the GCC banking systems and their macroeconomic effects, IMF Working Paper, 10/224, pp. 1-25, 2010.

Fofack, H., Non-performing loans in Sub-Saharan Africa: Causal analysis and macroeconomic implications, World Bank Policy Research Working Paper, No. 3769, pp. 1-36, 2005.

Ghosh, A., Banking-industry specific and regional economic determinants of nonperforming loans: Evidence from US states, Journal of Financial Stability, Vol. 20, pp. 93-104, 2015.

Cheng, L.K., Kwan, Y. K., What are the determinants of the location of foreign direct investment?, The Chinese Experience Journal of International Economics, Vol. 51, Issue 2, pp. 379-400, 2000.

Głogowski, A., Macroeconomic determinants of Polish banks'loan losses - results of a panel data study, NBP Working Papers 53, Narodowy Bank Polski, Economic Research Department, pp. 1-26, 2008.

Godlewski, C., Capital regulation and credit risk taking : Empirical evidence from banks in emerging market economies, Institut d'Etudes Politiques, Université Robert Schuman, Strasbourg 3, pp. 1-24, 2004.

Hausman, J., Specification tests in econometrics, Econometrica, 46, pp. 1251-1271, 1978.

Hsiao, C., Analysis of panel data, Econometric Society Monographs, No. 11. Cambridge University Press, New York 1986.

Hyde, A., Employee Organization and Employment Law in the Changing US Labor Market: America Moves Toward Shorter-Time Jobs, WP C.S.D.L.E. "Massimo D'Antona" . INT 10, 2002.

Jakubík, P., Reininger, T., Determinants of nonperforming loans in Central, Eastern and Southeastern Europe, Focus on European Economic Integration, Issue 3, pp. 48-66. Oesterreichische Nationalbank, 2013.

Kennedy, P., A guide to econometrics, 6th edition. Blackwell Publishing, Malden, Massachusetts, 2008.

Khemraj, T., Pasha, S., The determinants of non-performing loans: an econometric case study of Guyana. Presented at the Caribbean Centre for Banking and Finance Bi-annual Conference on Banking and Finance, St. Augustine, Trinidad, 2009.

Klein, N., Non-performing loans in CESEE; determinants and impact on macroeconomic performance, IMF Working Papers, 13/72, pp. 1-27, 2013.

Louzis, D., Vouldis, A., Metaxas, V., Macroeconomic and bank-specific determinants of nonperforming loans in Greece: A comparative study of mortgage, business and consumer loan portfolios, Working Paper, No. 118, pp. 1-44, 2010.

Maddala, G. S., Introduction to econometrics, 3rd edition, Chichester, John Wiley and Sons, 2001.

Makri, V., Tsagkanos, A., Bellas, A., Determinants of non-performing loans: the case of the eurozone, Panoeconomicus, 2, pp. 93-206, 2014.

Messai, A. S., Jouini, F., Micro and macro determinants of non-performing loans, International Journal of Economics and Financial Issues, 3(4), pp. 852-860, 2013. 
Nkusu, M., Nonperforming loans and macro financial vulnerabilities in advanced economies, IMF Working Paper, 11/161, pp. 1-28, 2011.

Petkovski, M., Kjosevski, J., Jovanovski, K., Empirical panel analysis of non-performing loans in the Czech Republic. What are their determinants and how strong is their impact on the real economy?, Czech Journal of Economics and Finance, 68, No. 5, pp. 460-490, 2018.

Pesola, J., Banking fragility and distress: An econometric study of macroeconomic determinants. Research Discussion Papers, 13, pp. 1-100, 2005.

Quagliarello, M., Banks'riskiness over the business cycle: a panel analysis on Italian intermediaries, Applied Financial Economics, 17(2), pp. 119-138, 2007.

Rajan, R., Dahl, C., Non-performing loans and terms of credit of public sector banks in India: An empirical assessment, Reserve Bank of India Occasional Papers, Vol. 24, pp. 81-121, 2003.

Rinaldi, L., Sanchis-Arellano, A., Household debt sustainability, what explains household nonperforming loans? An empirical analysis, Working Paper Series 570, pp. 1-45, European Central Bank, 2006.

Reinhart, C. M., Rogoff, K. S., Growth in a time of debt, American Economic Review: Papers \& Proceedings, 100, pp. 573-578, 2010.

Roodman, D., How to do xtabond2: An introduction to difference and system GMM in Stata, Stata Journal, Vol. 9, Issue 1, pp. 86-136, 2009.

Report of the working group on NPLs in Central, Eastern and South-East Europe: European Banking Coordination, Vienna Initiative, pp. 1-74, 2012.

Salas, V., Saurina, J., Credit risk in two institutional regimes: Spanish commercial and savings banks, Journal of Financial Services Research, Vol. 22, pp. 203-224, 2002.

Skarica, B., Determinants of non-performing loans in Central and Eastern European countries, Financial Theory and Practice, 38(1), pp. 37-59, 2013.

Strojwas, M., The Polish banking system: Hit by the crisis or merely by a cool breeze?, Economic analysis from the European Commission's Directorate-General for Economic and Financial Affairs, pp. 1-7, 2010.

Swamy, V., Impact of macroeconomic and endogenous factors on non-performing banks assets, International Journal of Banking and Finance, Vol. 9, Issue 1, pp. 27-47, 2012.

The European Banking Federation, Poland's banking sector: Facts \& Figures, 2018.

Vogazias, D. S., Nikolaidu, E., Investigating the determinants of nonperforming loans in the Romanian banking system: An empirical study with reference to the Greek crisis, Economics Research International, Vol. 2, pp. 1-13, 2011.

Wooldridge, J. M., Econometric analysis of cross section and panel data, MIT Press Books,

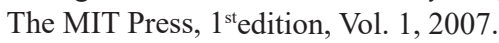

Yang, J., Kolari, J. W., Min, I., Stock market integration and financial crises: The case of Asia, Applied Financial Economics, 13:7, pp. 477-486, 2003.

Received: November 2019, revised: October 2020 